\title{
在館者の行動にもとづく火災フェイズのとらえ方
}

\author{
火災フェイズの概念にもとづく避難安全性の評価方法に関する研究（その 1 ) \\ THE ESTABLISHMENT OF THE PHASES OF FIRE SPREADING \\ PROCESS FROM A POINT OF VIEW OF HUMAN BEHAVIOR
}

-A study on evaluation method of life safety in case of building

fire based on the fire phase model ; No.1-

\author{
矢代 嘉 郎* \\ Yoshiro YASHIRO
}

\begin{abstract}
This paper describes the fire phases which I propose through analyzing the records of occupant's behavior in the building fires.

The purpose of this analysis is to establish the fire phases as a fire spreading process model in order to set conditions of the analytical evaluation method of life safety. The method of this analysis is to understand the relation between human behavior and fire situation from the fire records. Fire phases are defined as different aspects about behavior through evaluating the indices of variety of behavior to the category of fire situation.

The data for the analysis are the records of occupant's behavior in the 2 severe fires, these are "Sennichimae Building Fire" and "Taiyo Department store Fire". As the result of the analysis, the 7 phases are established as the different aspects in building fire from a point of view of human behavior, and the causes which develop a building fire from phase to phase are determined.

This fire phase model is applied to the 81 fire records. It is explained that there are 5 types of building fire spreading process which have respective characteristics of life safety.
\end{abstract}

Keywords : fire phase, building firesafety, human behavior

\section{1. 研究の目的と視点}

\section{1 研究の目的}

本報は，建築の火災対策を合理的に計画する方法の確 立をめざす研究の一環をなすものであり，避難安全性評 価の基礎として，火災時の人の行動から，様相の異なる 火災の局面（以下，火災フェイズという）を設定したも のである。

近年, 建築の多樣化や大規模複合化により，従来の防 災対策の前提を超えるような空間の出現や，より合理的 な対策をめざした新たな対策の提案が増加している。こ うした背景により建築の防災計画も転機を迎えつつあ る。それは, 従来の法令対応の計画加性能論的計画方 法をめざして，火災性状の予測にもとづき避難安全性な どを評価する手法が開発され，実用化の段階にいたった ことである刘。しかし，実際の設計ではまだこの方法 を一般的に利用できるまでには至っていないのが実状で
ある。その原因は，防災計画にもとづいて火災性状を予 測評価する状況や防災対応などを条件として設定しなけ ればならないが，その方法が一般化されていないためで あると考えられる。

こうした問題にたいして，本報は，火災拡大過程のモ デルを防災対策の体系化と防災計画のストーリーにもと ついた避難安全性評価のシナリオ" るため，火災の拡大過程を非連続的な局面の進展として とらえる視点にたち，火災時の行動を基準にして，火災 フェイズを設定することを目的としている。すなわち， 防火ならびに他分野における災害状態のとらえ方を考察 し，火災フェイズの概念と要件を設定する。そして，2 例の火災事例における行動記録から, 火災時の現象之行 動とのかかわりをとらえ，行動種類の分布にもとづいて 火災フェイズを設定する。さらに，この火災フェイズを 火災事例 81 例に適用することによって, 火災拡大過程 
の類型と特徴を把握し, 火災フェイズの避難安全性評価 における機能を確認する。

\section{2 防災計画方法に関する既往の研究と課題}

建築計画分野における防災計画研究を振り返えると, 避難などの要素技術の先駆的な研究效2) 4)に引き続き, 昭和 40 年代後半より総合的な防災計画の研究が始まっ た。すなわち, 昭和 47 年, 建築学会大会連合研究協議 会で,それまでの防災対策の法規定が必ずしも建築の特 性に適合せず，個別的，仕様書的であることや，設計が 法令を遵守するにとどまっている現実にたいして, 総合 的な計画の必要性が提起された站)。また, 同時期に大 火災が相次いだ。これらを契機として, 避難計画や対策 のシステム化や安全性評価などが研究されてきたせ2)。

このような防災計画研究の一方で, 行政面では昭和 56 年, 建築防災計画評定制度の発足により設計実務に おける防災計画が方向づけられ, 現在では標準といえる までになっている文6)。

こうした経緯を経て現在は, 防火性能の評価にもとづ いて対策を計画するという性能評価手法が開発され，実 用化の段階にいたっている。すなわち、これまでの燃焼 性状や煙挙動の解析手法の発達や, 避難計算手法の普 及文6)を背景に, 昭和 62 年火災性状の予測にもとづく防 火性能の評価手法がまとめられた（建設省総合技術開発 プロジェクト「防火設計法の開発」文〉ことである。こ の手法は, 従来の仕様的な対策の規定にたいして, 火災 性状の予測にもとづいて防火性能を評価するという画期 的なものではある。しかし，火災性状を予測評価するに あたって, 避難時の状況や非常時における防災対応など の, 防災計画にもとづいて予測評価する状況にいたる過 程とその状況下における要素を条件として設定する必要 がある。これは防災計画のストーリーにもとづく評価の シナリオの設け方といえるものであり, その方法が一般 のビル火災の拡大過程とのかかわりをもたせた形で確立 されているとはいえないことが課題であると考えられ る。

この問題に関連しては, 辻本 誠亡志田弘二は火災拡 大過程のシナリオの発生確率にもとづいてリスクを評価 する方法を示した文》。室崎益輝ほかは避難時間を左右 する覚知手段と避難開始時間を分析している文8。 。また, 筆者は評価にあたって設定する条件が結果に及ぼす影響 度合いを考察し，排煙設備の起動時間などの条件設定の しかたが結果を左右する要素を抽出した吝。しかし， ある条件下で評価はできても，その前提となる防災計画 のストーリーと評価の条件を結ぶシナリオの設け方を提 案するまでにはいたっていない。

一方, 火災拡大過程の時系列的なとらえ方として, 火 災フェイズの考え方が提案されている。これは，燃焼の 様相の変化亡いう特性から考えられたモデルであり, 火
災拡大の尺度ともされている畒)。また, 火災の局面に 対応させた形で対策が位置づけられる。そのため, 火災 フェイズによって火災拡大過程をモデル化することは, 防災計画のストーリーと評価の条件を結ぶシナリオの基: 礎となる考え方でもある。しかし，火災フェイズについ ては 2 章に記すように, 計画的意図からいくつかのモデ ルが提案されているが, 建築物の実際の火災との対応が 明確でなく, 計画の考え方にとどまっているのが実状で ある。

このような実状に対して, 避難安全性の評価にもとつ く合理的な対策の計画方法を確立するためには, 防災計 画と火災性状の予測評価のシナリオとを結ぶフレームと なる火災拡大過程のモデルが必要と考えられる。これを， 避難行動の側面からモデル化することが課題であると考 える。

\section{3 火災のとらえ方としての建築の状態の視点}

建築計画とは生活行為と空間の関係を体系的にとらえ る研究分野とされている文10)。この視点からみた安全性 の問題は, 非常時という状態を軸にした生活行為と空間 とのかかわりを問題にする分野と涀定できる。そして, 安全性の指標は, 生活行為に与える影響からみて, 建築 の安定的な状態から緊急な状態, 災害といわれる状態末 での「状態の緊急度」に相当する。また，防災計画は, 目標とする状態を超えて進展しないように対策機能を計 画することと規定できるであろう。

一方，災害の特性について論じた佐藤武夫ほかによる と, 災害は局面を変えながら拡大し，大災害になるとい う主旨が論じられている文11。建築の火災についても， 高野公男ほかによるビル火災の特異現象の報告文12)によ ると, 避難の観点からみた火災状況は, 煙の噴出などに より非連続的な様相を呈するものと考えられる。

つまり, 避難安全性を計画する観点からは, 火災の拡 大過程を，「様相が異なる局面」(火災フェイズ）が段階 的に進展するという非連続的な過程としてとらえるるこ が有効であろう。この局面を行動の緊急度の観点から区 分してとらえることによって, 火災フェイズは避難安全 性を評価するうえでの火災拡大過程のモデルになるもの と考えられる。

\section{2. 避難安全性評価における火災フェイズの考え方}

\section{1 災害状態の区分の実例}

火災を様相の異なる局面の進展過程としてとらえるた めに，防火分野ならびに他分野における計画対象の状態 の区分を示した例を摘出したものが表一1である。

表一 1 を概観すると, 守屋秀夫は e の温度に表れる火 災の物理性状をモデル化し,防災対策の機能を位置づけ, 防災計画の規範とした文13!。これに対して，H.E. Nel. son はc のモデル文14)を, 森下弥三郎も住宅火災につい 
表一1 災害ならびに計画対象の状態区分の例

\begin{tabular}{|c|c|c|c|c|c|c|c|c|}
\hline 段陌 & $\begin{array}{l}\text { a. } \\
\text { Cazard } \\
\text { Class }\end{array}$ & 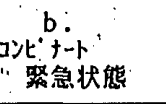 & Fire $\underset{\substack{\text { Behavior } \\
\text { Sequence }}}{c}$ & 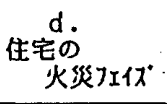 & 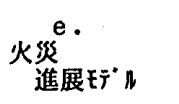 & $\begin{array}{l}f \\
\text { 消防庁の } \\
\text { 火災7I1X: }\end{array}$ & ${ }_{\text {意战の }}^{8 .}$ & 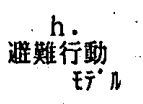 \\
\hline I & Safe & 不調 & $\begin{array}{l}\text { Ignition } \\
\text { Initiation }\end{array}$ & 着火物燃燒 & $\begin{array}{l}\text { （無炎着火） } \\
\text { 㮩焼 }\end{array}$ & $\begin{array}{l}\text { 真火宕かか } \\
\text { 否不明 }\end{array}$ & 睡眠状態 & 平常状態 \\
\hline II & Marginal & 故匴 & $\begin{array}{l}\text { InItial Itew } \\
\text { Development }\end{array}$ & 室内同部燃焼 & 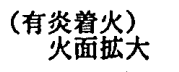 & 火災初期 & 居眠り状態 & 繠张状態 \\
\hline m & Critical & 異常 & $\begin{array}{l}\text { Intra-Room } \\
\text { Development }\end{array}$ & 天井面拡大 & $\begin{array}{l}(F \text { O) } \\
\text { 全体火災 }\end{array}$ & $\begin{array}{l}\text { 室内盛期 } \\
\text { \& 消防到着 }\end{array}$ & $\begin{array}{l}\text { 正常 } \\
\text { リランクス状態 }\end{array}$ & 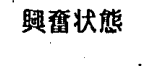 \\
\hline $\mathrm{N}$ & $\begin{array}{c}\text { Catastro } \\
\text {-phic }\end{array}$ & 事故 & $\begin{array}{l}\text { Inter-Spacial } \\
\text { Development }\end{array}$ & 全室内的燃焼 & $\begin{array}{l}\text { （火災荷重燒失） } \\
\text { 余媪 }\end{array}$ & $\begin{array}{r}\text { 他区画へ } \\
\text { 延焼 }\end{array}$ & 正常张状態 & \\
\hline v & & 災害 & $\begin{array}{l}\text { Inter Compar- } \\
\text { tment Develop. }\end{array}$ & 室間执大 & （顛火） & & 塸急状能 & . \\
\hline $\mathrm{VI}$ & & & & 粄全焼 & （）内は現象 & & & \\
\hline 指 & 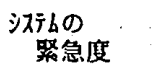 & $\begin{array}{l}\text { 㳊ibの } \\
\text { 㗨急度 }\end{array}$ & $\begin{array}{l}\text { 火災の } \\
\text { 胅大領域 }\end{array}$ & $\begin{array}{l}\text { 火災の } \\
\text { 拡大领域 }\end{array}$ & 燃焼性状 & $\begin{array}{l}\text { 対策の対応 } \\
\text { する現象 }\end{array}$ & 媵波の & 心理状態 \\
\hline 出 & $\begin{array}{c}\text { U.S. Army } \$ 18 \\
74\end{array}$ & 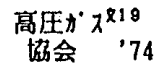 & $\begin{array}{r}\text { Nel son }{ }^{\$ 14} \\
\quad 76\end{array}$ & 森下 ${ }^{216}, 77$ & 守屋 ${ }^{\searrow 13}$ ?78 & 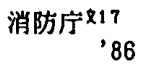 & 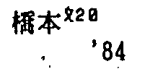 & 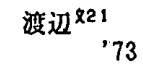 \\
\hline
\end{tabular}

て同様な概念の d を提案した文15)。これらは，火炎の然 焼域から拡大過程をモデル化したもので, 火災拡大の確 率的分析につなげている文16)。また，消防庁では火災フェ イズを「建築物総合防災システムを火災対処機能として 対応させるうえで，火災成長の時系列的展開を示す必要 があることから設定した概念」として「発災時に予想さ れる各々の事象」と定義し，fの4段階を設定し, 防災 設備の対応を規定している文17)。

一方, システムエンジニアリングの分野においては， a の Hazard Classification の考え方畒佀がある。これは システムの緊急度あるいは機能の度合いを示しているも のである。bのコンビナートの安全指針畒19 もこれに同 様である。

行動安全にかかわるものをみると，橋本邦衛は脳波の 型が異なる $\mathrm{g}$ の緊急度合いのフェイズ坟价が存在するこ とを解明し, 人間工学分野での安全設計の基礎をなした。 また，避難行動においては，渡辺仁史は心理状態を $\mathrm{h} の$ ように区分した避難モデルを提案している坟1。

なお，三村由夫は出火防止，感知覚知警報，初期展炎 防止初期消火, 拡大延焼防止, 避難, 煙制御, 消火救助 という区分に対策を位置づけた刘。。これも一般には火 災フェイズとされているが，むしろ，火災の拡大過程に ほぼ対応した対策の機能的分類であると考えられる。

\section{2 火災ブェイズの考え方と要件}

災害状態の区分の例では，災害の性状と計画対象の状 態との組み合わせから 3 つの類型がみられる。一つは, 物理的あるいは生理的な性状の段階的変化を示すという 計画の基礎となるものであり，e や g がこれにあたる。 第二には, 空間概念を入れた $\mathrm{c}, \mathrm{d}$ や火災時の対応を示 すfであり，防災対策と対応がとれるように火災拡大を 段階づけている点に特徴がある。第三には対象の状態を

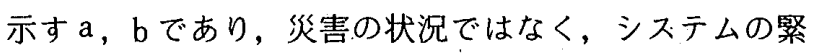
急度のレベルを設定している点が特徴である。以上の類 型は，安全性を計画するに際して与える機能により性格 づけられるものと解釈できる。つまり, 災害の進展過程 の区分は計画的概念であるとみなされる。

そこで，1.3 に示すように，避難安全性を行動と状態 のかかわりでみる視点にたつと, 火災フェイズは，安全 性の指標として行動に対する緊急度を表し，かうビル火 災の央状を記述でき, 対策機能を位置づけられるように 設定することが要件となる。

この観点から火災における状態区分の例をみると, 以 下のようである。e は防災計画の考え方を示しているが， 実火災への適用には難しい面がある。cとdは, 典型的 な燃焼拡大過程に限られ，ビル火災における避難などの 問題に適用するには改良を必要亡する。また， f は防災 設備の面で現象亡防災機能を対応づけているが, フェイ ズがある現象をさすか, 局面を意味するか明確ではない。 また，避難段階が大きくまとめられ，避難で問題となる 現象と行動との関係がとらえにくいと考えられる。

以上にたいして，ここでは避難安全性を評価する状況 とその状況にいたる過程のモデルとして, 火災拡大過程 を非連続的な局面の進展でとらえることを意図し，火災 フェイズを「行動に変化を及ぼす現象を契機とした行動 の様相の異なる火災の局面」と定義するものとする。こ の炎災フェイズの概念では；ある現象によって行動が変 化するまでは同じ火災状態が続いているものと仮定して おり, 複雑な現象もフェイズ内では定常的にみなそうと するものである。まだ あるフェイズを避難安全性の目 標レベルとし，そのフェイズまでの進展過程と進展の条 件を防災計画のストーリーにもとづいた安全性評価のシ ナリオにしようとするものである。 
3. 行動実態にもとづく火災フェイズの設定注引)

3.1 行動記録の分析ならびにフェイズ設定の方法

3.1 .1 行動記録の分析対象上分析方法

行動と火災状態の関係についての分析対象は, 表一2 に示す昭和 47 年の千日前ビル火炎（以下＜千日>と記 す）の被災者 35 人の行動記録文23), 出4) と, 昭和 48 年の大 洋デパート火災（以下＜大洋〉と記す）における被災者 46 人の行動記録进 ${ }^{2}$, 泣6)である。

この火災事例を分析対象としたのは，被災者のことば による記録であって, 被災時点の行動が詳述されている こと，破局的な段階にまでいたった火災であること，さ らに 1 人当たりの記述内容が多く, 火炎状態と行動の関 係を見いだしうる可能性が高いことによる。

行動記録の分析にあたっては, 図一1の図式のように, 局面を形成する火災現象と行動が対応するものと仮定す る。この図式にもとづき，行動記録文を分解し，行動の 変化とその起因を抽出する神),社8)。そして, 起因と行動 をおのおの同種のものをまとめる方法でカテゴリーを 設定し，起因カテゴリーと行動カテゴリーの関係による

表一2 分析対象者の属性

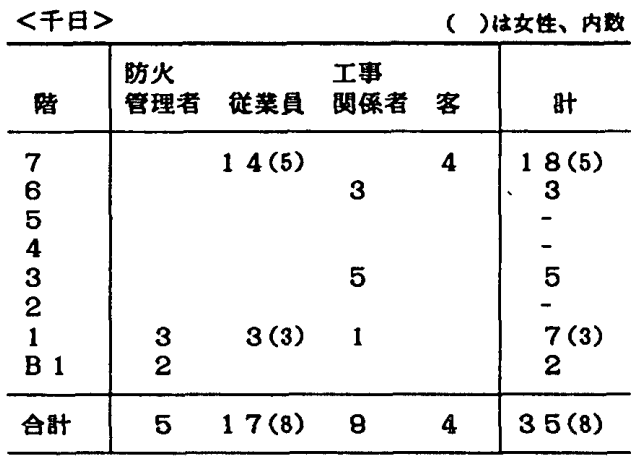

\begin{tabular}{|c|c|c|c|c|c|}
\hline \multicolumn{2}{|c|}{ 洋> } & & \multicolumn{3}{|c|}{ の推定制、内数 } \\
\hline 陵 & $\begin{array}{l}\text { 防火 } \\
\text { 管理渚 }\end{array}$ & 従葉具 & 工軎 & 客 & 旪 \\
\hline $\begin{array}{l}9 \\
8 \\
7 \\
6 \\
5 \\
4 \\
3 \\
2 \\
1 \\
\text { B } 1\end{array}$ & 1 & $\begin{array}{l}4<4> \\
6<6> \\
4<2\rangle \\
3<3> \\
7<5> \\
2<1> \\
6<5> \\
2\end{array}$ & $\begin{array}{l}1 \\
1\end{array}$ & & $\begin{array}{l}1 \\
1 \\
4<4> \\
6<6> \\
4<2> \\
3<3> \\
8<5> \\
2<1> \\
8<5> \\
2\end{array}$ \\
\hline 地上 & & 1 & 6 & & 7 \\
\hline 合旪 & 1 & $35<28>$ & 10 & - & $46<28>$ \\
\hline
\end{tabular}

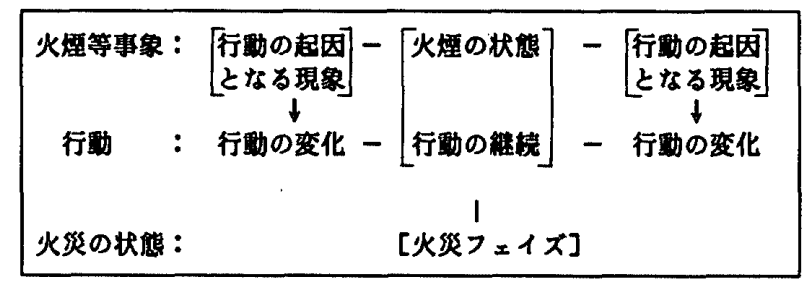

図一1 火災現象と行動との対応についての仮説
記述数を分析のデータとする。

なお，火災時の在館者の行動について，小林正美と堀 内三郎はオフィスビルの火災事例における行動を分析 し, 非常時の行動は避難者の社会的属性に影響されると ともに，潜在的な危険回避の行動があることを報告して いる対4。しかし，本報では，主に従業員が対象となっ ているデータであるため属性には配慮せず，単純に現象 と行動のみを関係づけて分析する。この点については, 非常時の対応などの行動に変化を起こす現象をとらえる という限定した目的であるため, 各種の行動が甬想され る従業員を主とした分析であっても支障は少ないものと: 考えた。

\section{1 .2 類似度による火災フェイズ設定方法}

起因にたいして行動種類の分布が類似していれば，そ の起因は同じ局面にあるものと考え, 起因カテニ゙リー別 の行動カテゴリーの記述の分布から, 起因カテニ゙リー間 の類似性によって局面を形成する起因を識別する。すな わち, 行動の様相を基準として, ある起因から次の起因 までの局面を設定し，これを火災フェイズとする。

ここで, 類似の判断には地域の生態的類似性を指標化

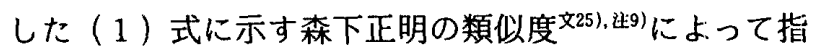
標化する。さらに, 各起因カテゴリ一間の類似度の逆数! $1 / C_{i s}$ をユークリッド距離とみなして, 群平均法を分離 基準としたクラスター分析により，行動分布が類似する 起因をまとめる。

$$
\begin{aligned}
& C_{i j}=\frac{2 \sum_{k=1}^{m} n_{i k} n_{j k}}{\left(\lambda_{i}+\lambda_{j}\right) N_{i} N_{j}} . \\
& \lambda_{i}=\frac{\sum_{k=1}^{m} n_{i k}\left(n_{t k}-1\right)}{N_{i}\left(N_{i}-1\right)}
\end{aligned}
$$

$C_{i j}:$ 起因カテゴリ $-i, j$ 間の類似度

$\lambda_{i}:$ 起因カテゴリー $i$ の多様度

$n_{i k}:$ 起因カテゴリー $i$ の中の行動種 $k$ の数

$N_{i}$ : 起因カテゴリー $i$ の中の総数

$m:$ 行動カテゴリー数

\section{2 非常時の行動と起因との関係}

火災時の状況と行動の記述から, 行動とその起因とな る現象（または状態）を抽出し，グルーピングした。そ の結果, 行動については表一 3 の 23 項目にまとめた。 これらは防災上の行動目的からみると 10 種類になる。 行動の起因については, 単に火煙の状況のみだけでなく, 避難誘導や周辺の群集の状態なども挙げられている。こ れらを同じ状況を示していると判断されるものをグルー ピングし，表一4の 16 項目にまとめた。

この起因と行動のカテゴリーによって行動記述をプ ロットしたのが表一5である。その結果，〈千日>では 時系列的に発生する現象にそって,火災確認の行動加ら, 避難, 脱出という行動へ順次変化している傾向がみられ 
る。しかし，〈大洋〉では，火災初期段階では煙の発見 や叫び声などによる確認や初期対応行動に特定される が，その後はかなり分散しており，火災が進展したと考 えられる現象にたいしても消火や避難などの行動がみら れる。

両者の相違は，〈千日>では分析対象者が集中してい る 7 階に火煙が噴出し, 全員が同時に緊急な事態になっ たことにたいし，〈大洋〉では営業中の百貨店の火災の ため, 従業員や工事関係者による対処行動が行われてい るためであろう。

なお，〈千日>の客 4 人は煙発見により，直ちに避難

表一3 記録文中の行動のカテゴリー

\begin{tabular}{|c|c|c|}
\hline & $\begin{array}{l}\text { : B1；平常 } \\
\text { ：B2；通報する }\end{array}$ & 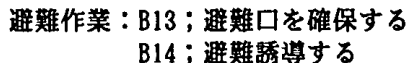 \\
\hline & B3; 叫ふ心 & 避難 : $\mathrm{B15}$; 避難する \\
\hline 確認行動 & : B4；かけつける & B16 ; 避難方向を变える \\
\hline & $\begin{array}{l}\text { B5；火元の確認 } \\
\text { B6；周囲を見る }\end{array}$ & $\begin{array}{c}\text { 脱出 : B17；こする、うろっく } \\
\text { B18；眖出口を探す }\end{array}$ \\
\hline 防火 & $\begin{array}{l}\text { B7；非常放送する } \\
\text { B8；待機する } \\
\text { B9；董要物の持出し } \\
\text { B10;延焼防止の作菜 }\end{array}$ & $\begin{array}{c}\text { B19；脱出する } \\
\text { 救助 }: \text { B20; 助けを求める } \\
\text { B21； 救助される } \\
\text { 救助する }\end{array}$ \\
\hline 消火作業 & $\begin{array}{l}\text { : B11;消火作業の準㑤 } \\
\text { B12;消火する }\end{array}$ & $\begin{aligned} \text { その他:B22；見ている } \\
\text { B23；知人を探す }\end{aligned}$ \\
\hline
\end{tabular}

表一4 記録文中の行動起因のカテゴリー

\section{$\mathrm{E} 1$ : 平常}

$\mathrm{E} 2:$ 炷発見

E3：火事の声、音、臭い

E4：火災確琶、煙の確認

E5：防火作業者の指示

E6：防火作業の完了、失敗

$\mathrm{E7}$ : 炎があがる (消火失敗)

E8：煙の嗔出、火の韻出

\section{E9：避難路なし、避難の指示}

E10：黒煙加噴出、执大

E11：人が殺到

E12：避難誘導、避難群集殺到

$\mathrm{E} 13$ ：脱出口なし、救助者の声

E14：黑煙充渵、悹明り、先望者

E15：飛び降り

$\mathrm{E} 16$ ：救助隊の到着
していることから，客の行動は従業員とは大きく異なる ことが十分予想されることを注記する。

\section{3 起因間の類似度による火災フェイズの設定}

火災フェイズの契機となる起因として，表一 4 の 16 項目のままでは火災フェイズに対する行動の様相を識別 できない。そこで，類似した起因をまとめるために，起 因間の行動分布の類似性を指標化したものが表一6の類 似度 $C_{\iota \jmath}$ である。

これを,各起因間の類似度の逆数 $1 / C_{t j}$ を距離として, 群平均法を分離基準としたクラスター分析によりまと

表一6 行動分布にもとづく起因間の類似度 $\left(100 C_{i j}\right)$ 千日/大 洋

\begin{tabular}{|c|c|c|c|c|c|c|c|c|c|c|c|c|c|c|c|c|c|c|}
\hline & $\mathrm{E}_{1}$ & $\begin{array}{c}\mathbf{E} \\
{ }_{2}\end{array}$ & $E_{3}$ & $E_{4}$ & $E_{5}$ & $\varepsilon_{6}$ & E & E & & & & 118 & \begin{tabular}{|l|l} 
& $\mathrm{E}$ \\
\end{tabular} & 13 & \begin{tabular}{l|l}
$E$ & $B$ \\
14 & 1
\end{tabular} & \begin{tabular}{c|c}
$E$ & $E$ \\
15 & 1
\end{tabular} & ${ }_{18}^{E}<$ & 〈大洋〉 \\
\hline & & 15 & 0 & 0 & 0 & 0 & & 1 & & 0 & 0 & 0 & 0 & 0 & 0 & 0 & 0 & E 1 \\
\hline E 1 & & & 210 & 43 & 85 & 19 & & 1 & & 3 & $43 \mid 1$ & 15 & $13 \mid 0$ & & 0 & 0 & 0 & E 2 \\
\hline E 2 & 0 & & & 188 & 282 & 36 & & 8 & & 0 & 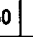 & 0 & 0 & 0 & 0 & 0 & 0 & E 3 \\
\hline E 3 & 0 & 90 & & & 98 & 88 & 65 & 8 & & 8 & 88 & \begin{tabular}{l|l}
88 & 7
\end{tabular} & 13 & 2 & 5 & 0 & 7 & $E_{4}$ \\
\hline B 4 & 0 & 28 & 89 & & & 70 & 4 & 2 & & 5 & 23 & 4 & 0 & 0 & 0 & 0 & 0 & E 5 \\
\hline E 5 & 0 & 0 & 0 & 8 & & & 11 & 16 & & 6 & 10 & 12 & 17 & 2 & 0 & \begin{tabular}{l|l}
0 & 3 \\
\end{tabular} & 34 & E B \\
\hline E 6 & 0 & 0 & 22 & 51 & 30 & & & 4 & & 4 & 15 & 20 & 15 & 14 & 15 & \begin{tabular}{l|l}
0 & 5
\end{tabular} & 57 & E 7 \\
\hline E 7 & 0 & 21 & 0 & 23 & 0 & & & & & 9 & 32 & \begin{tabular}{l|l}
39 & 9
\end{tabular} & 34 & 2 & 5 & \begin{tabular}{l|l}
0 & 1
\end{tabular} & 12 & E 8 \\
\hline E 8 & 0 & 34 & 14 & 65 & 0 & 27 & 7 & & & & \begin{tabular}{l|l}
30 & 1 \\
\end{tabular} & \begin{tabular}{l|l}
03 & 12
\end{tabular} & 26 & 18 & \begin{tabular}{l|l}
60 &
\end{tabular} & $10 \quad 2$ & 24 & E 9 \\
\hline E 9 & 0 & 0 & 0 & 7 & 0 & & & & & & & $\begin{array}{ll}88 & 1\end{array}$ & \begin{tabular}{l|l}
36 & 1
\end{tabular} & 15 & \begin{tabular}{l|l}
24 & 1
\end{tabular} & \begin{tabular}{l|l}
17 & 3
\end{tabular} & 31 & E10 \\
\hline E10 & 0 & 53 & 0 & 97 & 0 & & 10 & $0 \mid 2$ & & 56 & & & 20 & 4 & \begin{tabular}{l|l}
31 & 1
\end{tabular} & $\begin{array}{ll}17 \quad 1 \\
\end{array}$ & 14 & E11 \\
\hline E11 & 0 & 11 & 0 & \begin{tabular}{|l|}
18 \\
\end{tabular} & 0 & & 3 & & 78 & 342 & 80 & & & 13 & 43 & $\begin{array}{lll}0 & 2\end{array}$ & 21 & E12 \\
\hline E12 & 0 & 18 & 0 & 22 & 0 & & 4 & & 8 & 88 & 50 & 24 & & & $\begin{array}{ll}71 \\
\end{array}$ & \begin{tabular}{l|l}
10 & 8 \\
\end{tabular} & 88 & E13 \\
\hline E13 & 0 & 0 & 0 & 7 & 0 & & & 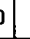 & 0 & 13 & 0 & 26 & 77 & & & \begin{tabular}{l|l}
52 & 1
\end{tabular} & 126 & E14 \\
\hline E14 & 0 & 11 & 0 & \begin{tabular}{|l|}
18 \\
\end{tabular} & 0 & & & 0 & 0 & 14 & 65 & \begin{tabular}{l|l}
68 & 1 \\
\end{tabular} & 44 & 99 & & & 34 & E15 \\
\hline E16 & 0 & 0 & 0 & 0 & 0 & & I & 0 & 0 & 0 & 0 & 0 & 0 & 0 & 0 & & & E16 \\
\hline E16 & 0 & 0 & 0 & 0 & 0 & & & & 0 & 0 & 0 & 0 & 0 & 0 & 0 & 0 & & \\
\hline F日一 & $E_{1}$ & 2 & 3 & $\varepsilon_{4}$ & & & & & & 1 & \begin{tabular}{|l|l|l|l|}
10 & \\
10
\end{tabular} & \begin{tabular}{|l|l}
$\mathbf{E}$ & \\
11 & 1
\end{tabular} & \begin{tabular}{l|l}
${ }_{12}$ \\
\end{tabular} & $\begin{array}{l}E \\
13\end{array}$ & \begin{tabular}{|l|l|}
$E$ \\
14
\end{tabular} & \begin{tabular}{l|l}
$\mathbf{E}$ \\
15
\end{tabular} & $\begin{array}{l}\mathrm{E} \\
18\end{array}$ & \\
\hline
\end{tabular}

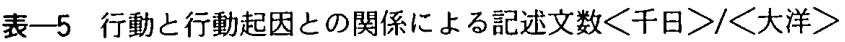

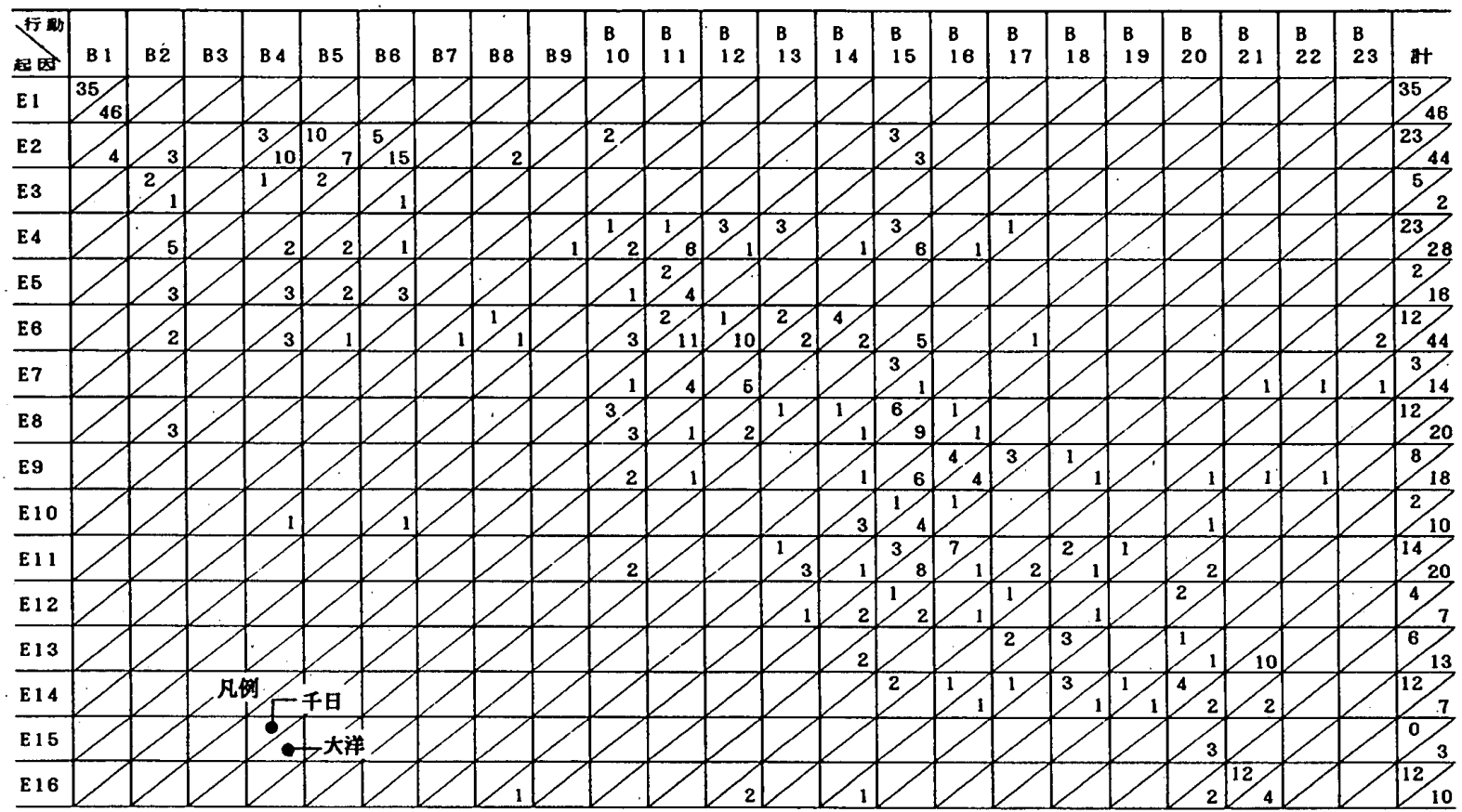




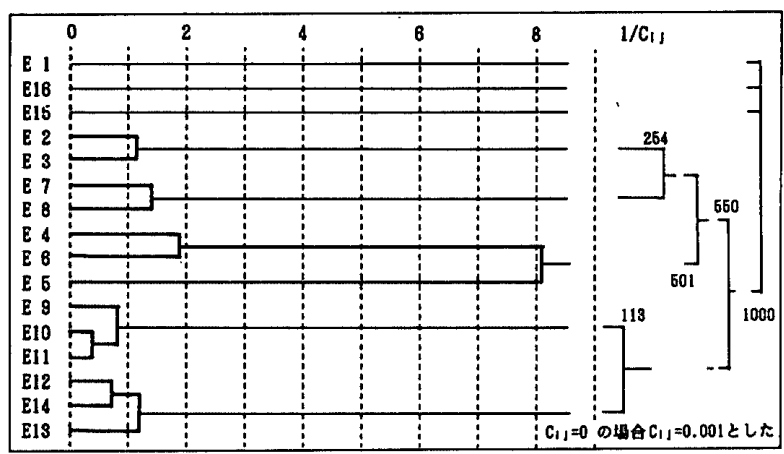

図一2 起因間の類似度によるクラスターく千日>

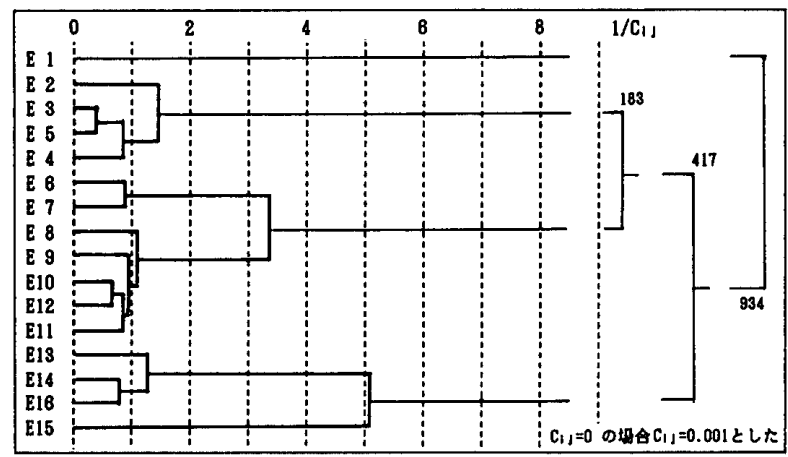

図一3 起因間の類似度によるクラスターく大洋〉

め, デンドグラムで表したものが図一2, 図一 3 である。 図一 2 , 図一 3 にみられように, <千日>では大き く距離が変わる点 $\left(1 / C_{i j} \geqq 8.2\right)$ がある。しかし，この 基準でく大洋>をみると，〈千日 $>8$ 区分と $<大$ 洋 $>4$ 区分となり，局面の区分が大幅に異なる。そこで，両者 に共通する区分とするために，両者の起因区分が対応す るように各々に別の基準 (<千日 $>; 1 / C_{i j}=8.2$ ， <大 洋>; $\left.1 / C_{t j}=2.0\right)$ によって区分すると, 以下に示すよ うなく千日>で 8段階, 〈大洋>で 6 段階の区分で, 起 因もほぼ相互に対応するようになる。

$$
\text { 〈千日><样> }
$$

\section{(1) $\bullet$ E1}

(i) $\bullet$ E1

(2) $\bullet \mathrm{E} 2, \mathrm{E} 3$

(ii) $\bullet$ E2, E 3, E4, E5

(3) $\bullet$ E4, E5, E6

(iii) $\bullet \mathrm{E} 6, \mathrm{E} 7$

(4) $\bullet$ E7, E 8

(5)・ E9, E10, E11 (iv) E8, E9, E10, E11, E12

(6) $\cdot \mathrm{E} 12, \mathrm{E} 13, \mathrm{E} 14$

(v) $\bullet$ E13, E14, E16

(7) $\cdot \mathrm{E} 15$

(vi) $\cdot \mathrm{E} 15$

(8) $\cdot \mathrm{E} 16$

以上の手続きから求めたく大洋〉とく千日>における 区分の相違点は, 以下の 3 点である。

(1) 〈千日>では主に避難行動にかかわる起因が（4)

（5）の 2 区分となるが，〈大洋〉では（iv）の1区 分でる。

(2) E4，E5，E8やE12 のように<千日 ><大洋>間 で起因の属する区分にずれがある。

(3) 〈大洋〉ではE16 救助活動が独立していない。
上記の11の避難行動を引き起こす段階の相違について は，<千日>では主に避難準備と避難行動に分割された ものが，〈大洋〉では避難や避難誘導などの作業が火災 が進んだ現象にたいしてもみられるため，分割できない 結果となっているものと考えられる。(2)の起因現象の属 する区分のずれについては，〈千日＞に比べてく大洋〉 では火災への対応は早いが, 危険に対する回避行動が㷟 れており，従業員の責任を果たす目的行動が続いている 傾向となっている。(3の救助活動については，〈大洋〉 では消防隊が到着後も工事関係者は救出作業等に従事し ているため, 他の起因と結びついているものである。

これら 3 点の相違の原因には, 〈千E>では, 分析対 象者の多い階に急激に煙が噴出したため, 在館者が一様 な行動をしている傾向があるのにたいし，〈大洋〉では 全館が同時に危険になったのではなく，火災が進んだ段 階でも従業員之工事関係者の各種の対処行動が続けられ ていたことが影響しているものと考えられる。

両者には以上のような相違がみられるため，一概に比 共通の火災フェイズを規定できない。そこで，耐者に共 通の火災フェイズとするために，火災フェイズ敒火災搪 大の時系列的局面であることと, 行動にとっての状態の 緊急度を表すものであるという点から, 状態区分の防災 計画への適用性を判断して設定するものとする。

この考え方をとると，＜千日>の主に避難行動にかか わる段階の 2 区分が緊急度の違いによっているものと解 釈され，〈大洋>の主に従業員の特性によって細分でき ない結果となっていると判断される 1 区分よりも防災対 策を位置づけやすく，防災計画上有効であると孝えられ る。また, 個々の起因の属する区分の違いについては, 起因が 1 段階進んだ区分に含まれているく千日>を基洮 にするのが安全側となる。さらに，救助活動については， 時系列的にみて脱出の失敗から救助されるか, あるいは パニックになるものと考えると, 救助とパニック的行動 とを同じ局面とすることが妥当であると考えられる。

以上の手続きにより, 平常状態も入れて, 表-7の 7 段階の火災フェイズを設定した。

この設定した 7 段階の火災フェイズごとの行動の様相 がそれぞれ固有であるか否かを確認するために，表一门 の 16 項目の起因を, この 7 区分にま亡めてフェ.イズ間 の行動分布の類似度をとったものが表一8である。表一6 と表一 8 の類似度の平均を比較すると, <千E>では $C_{i s}=0.230$ が 0.162 に, <大洋>では $C_{i j}=0.360$ が 0.251 というように約 7 割に減少している。つまり, 彷 業員の多梯な行動のため, 避難にかかわる II N段階では 必ずしも区分の固有性は明確ではないが, 全体として設 定した火災フェイズごとの行動の個別性が増し, 様相の 異なる局面を設定するという趣旨が生かされたものと解 釈できる。 
表一7行動にもとづく火災フェイズと主な起因

\begin{tabular}{|c|c|c|c|}
\hline \multirow[t]{2}{*}{ 火災 7} & \multirow[t]{2}{*}{ 主な行堪 } & \multicolumn{2}{|c|}{ 圭梠起因。 } \\
\hline & & 火㮒の現象 & 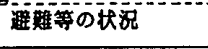 \\
\hline 0 ；平常状態 & 平㦂行躭 & & \\
\hline I；異常発生碓琵 & $\underset{1}{b}$ & 煙発見 & $\begin{array}{l}\text { 问異常 } \\
\text { 火串の声 }\end{array}$ \\
\hline II ; 初期対処状態 & 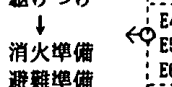 & 䙳磼略 & $\begin{array}{l}\text { 対庆者指示、 } \\
\text { 防火·消火作業失敗 }\end{array}$ \\
\hline U；避赫状態 & 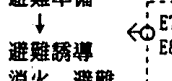 & $\begin{array}{l}\text { 炎があがる } \\
\text { 煙厸大、煙啫出 }\end{array}$ & \\
\hline N ; 聚急避㴶状態 & 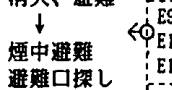 & $\begin{array}{l}\text { 黑煙嗔出 } \\
\text { 黑煙せまる }\end{array}$ & $\begin{array}{l}\text { 避觹者移到 } \\
\text { 澼踓路なし }\end{array}$ \\
\hline $\mathrm{V}$; 危急状態 & 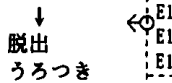 & 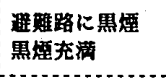 & 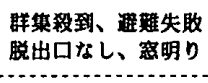 \\
\hline VI; $\begin{array}{c}+ \\
\substack{+ \\
\text { 数助 }}\end{array}$ & 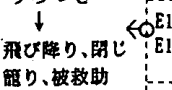 & & 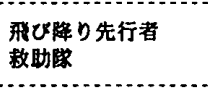 \\
\hline
\end{tabular}

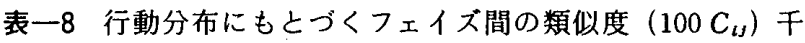
日/大洋

\begin{tabular}{|c|c|c|c|c|c|c|c|c|c|c|c|}
\hline 0 & & & & 0 & I & II & DI & $\mathbf{N}$ & $v$ & v & 大洋 \\
\hline I & 0 & & & & 15 & 0 & 0 & 0 & .0 & 0 & 0 \\
\hline II & 0 & 26 & & & & 41 & 18 & 20 & 2 & 2 & I \\
\hline III & 0 & 28 & 37 & & & & 91 & 48 & 2 & 14 & II \\
\hline N & 0 & 21 & 35 & 99 & & & & 83 & 23 & 24 & II \\
\hline$v$ & 0 & 7 & 11 & 31 & 45 & & & & 38 & 24 & $\mathrm{~N}$ \\
\hline VI & 0 & 0 & 0 & 0 & 0 & 0 & & & & 87 & $\mathrm{~V}$ \\
\hline 千日 & 0 & I & II & II & $\mathbf{N}$ & $\mathrm{v}$ & $\mathrm{v}$ & & & & VI \\
\hline
\end{tabular}

\section{4 火災フェイズ別の行動の特徴}

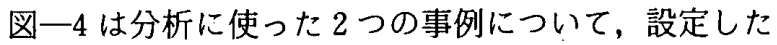
各フェイズごとの行動の多様性から火災㹡大過程におけ る行動特性を再整理したものである。ただし，行動は 23 項目ではなく，防災上の目的行動として表一3にしる す 10 種にまとめて，(2) 式によって多様度入を求めた。

$2 つ$ 事例とも, 火災初期では一様な行動を示してい る。しかし，避難も行われている II III の状態では多様な 行動がみられることがわかる。さらに危急的状態になる と行動は再び一様化する。この傾向はく千日〉で顕著で

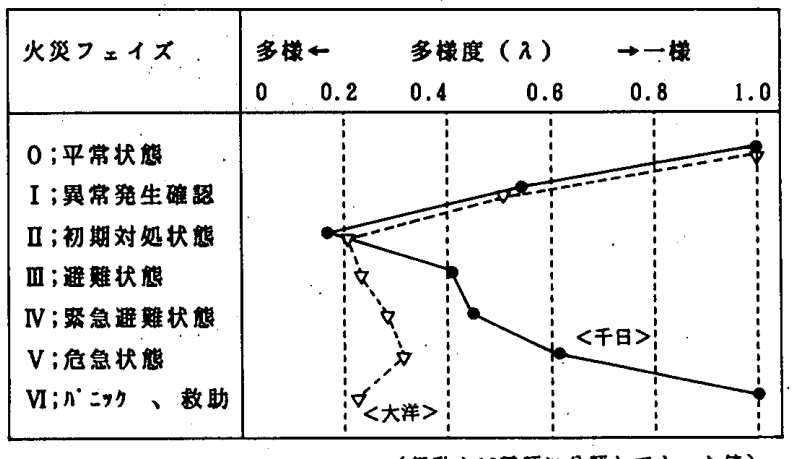

図-4 火災フェイズ別の行動の多様度
ある。<大洋〉でも明確ではないが, 徐々に一様化する 傾向はみられる。すなわち，火災初期と緊急性が増した 段階では, 被災者の属性にはかかわらない一様な行動之 なるといえる。また，緊急を要したく千日>でも一時的 に多様な行動となることは，実際の火災における行動特 性の一つとして避難安全性評価において配慮すべき事実 であると考えられる。

以上の結果より, 非常時の行動の観点からも火災拡大 過程は非連続的な局面の進展としてみることができると 考えられる。その火災フェイズごとの典型的な行動は, 火災初期の I， IIのフェイズには在館者はすぐに避難す るのではなく，火災を確認し，初期の対処行動をとる。 煙の拡大などによって始まるIIIのフェイズでは避難する 者, 誘導する者; 消火なよ゙の作業につく者など多様であ り，避難開始を一律に規定することはできない。黒煙の 噴出などによって始まる IVでは，避難口を探したり，殺 到するなどの群集パニックに近い避難状態になり，行動 も一様化する。さらに, 黒煙充満や群集殺到や避難路に 煙噴出などによるVのフェイズでは脱出に一様化する。 また，飛び降りなどの先行者がみられると，それに続い

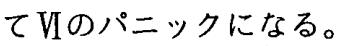

これは，ごく一般的に理解される過程ではあるが，様 相の異なる局面が規定され, 行動の特徴と避難安全性に たいして重要といえる局面がかわる起因が実態から確認 されたといえるであろう。

\section{4. 火災フェイズによる火災拡大過程の分析}

\section{1 火災フェイズの適用方法}

設定した火災フェイズの適用性をみるために，火災事 例の拡大過程の記述に適用し，フェイズの進展のしかた を考察する。そこで，東京消防庁でまとめた特異火災 112 例文26)のうち, 表一9 の特性をもつ2 階建て以上の耐 火造の火災記録 81 例を分析対象にして, 在館者の行動 についての記述とその時の火災状況から判断して, 前節 で設定した火災フェイズにプロットし，フェイズの進展 のしかたを類型的にとらえる。

その際，同じ火災事例の中にも場所によりフェイズの 進展に相違があるが，この分析においてはフェイズの進 屡過程に異なった記述があればそれも重複してプロット

\section{表一9. 火災㹡大過程の分析対象事例の特性と件数}

\begin{tabular}{|c|c|c|c|c|c|c|}
\hline 用途 & (件) & 延面輤 & 件) & 焼損面箖 & (件) & $\begin{array}{r}\text { 死者発生有無 } \\
\text { (件) }\end{array}$ \\
\hline ホテル旅饂 & 21 & $S<3000 u^{2}$ & 28 & $S<500 \mathrm{u}^{2}$ & 25 & 死者発生火災 50 \\
\hline 物販店舗 & 24 & $<6000$ & 17 & $<1500$ & $20:$ & 避難成功火㰥 31 \\
\hline 病院 & 8 & $<10000$ & 11 & $<3000$ & 19 & \\
\hline 場 & 5 & $<20000$ & 14 & $<6000$ & 6 & \\
\hline 䘽合用途 & 23 & $>20000$ & 11 & $>6000$ & $11 !$ & \\
\hline
\end{tabular}


するものとする。また，初期の段階で避難を終了した人 がいた場合でも，同じ過程をたどってさらに進展した フェイズにいたった避難者があれば，後者の進展過程に 含まれるものとしている。

なお，分析対象は限定された特異な火災事例であるの で統計的意味はなく，火災フェイズ進展の類型とその特 性の傾向を把握するにとどまるものである。

\section{2 火災拡大過程の類型}

適用対象の 81 事例について，火災フェイズの進展過 程と事例数を示したのが図一 5 である。分析した火災事 例では25 種類の異なった進展過程がみられた。このな かには，順次火災が拡大していく典型的なケースのみで なく，フェイズがスキップするという急激な進展過程の あるケースが多いことがわかる。特に，覚知段階や初期 避難段階がないまま，緊急避難あるいは脱出段階という 煙に直面するフェイズにいたっているケースが多い。

分析対象は主に特殊建築物の比較的大規模な火災が取 り上げられているが，このようなビル火災における避難 については，煙の噴出による緊急状態の発生などのよう に，燃焼域の空間的拡大に対応するような過程にはなら ないという特徴をものがたっている。

そこで，この 25 種類の火災フェイズ進展過程を, 死 者の発生にかかわりが深いと考えられるフェイズのス キップのしかたから類型化すると，以下に示す 5 類型に 分類できる。

\begin{tabular}{|c|c|c|c|c|c|c|c|c|c|c|}
\hline No & 0 & I & $n^{7}$ & $\begin{array}{l} \pm 1 \\
\text { III }\end{array}$ & & $\mathbf{V}$ & V & D & $\begin{array}{l}\text { 死者なし } \\
\text { 事列数 }\end{array}$ & $\begin{array}{l}\text { 死者発生 } \\
\text { 事例数 }\end{array}$ \\
\hline $\begin{array}{r}1 \\
2 \\
3 \\
4 \\
5 \\
7 \\
8 \\
9 \\
10 \\
11 \\
12 \\
13 \\
14 \\
15 \\
16 \\
17 \\
18 \\
19 \\
20 \\
21 \\
22 \\
23 \\
24 \\
25\end{array}$ & $\begin{array}{l}0 \\
0 \\
0 \\
0 \\
0 \\
0 \\
0 \\
0 \\
0 \\
0 \\
0 \\
0 \\
0 \\
0 \\
0 \\
0 \\
0 \\
0 \\
0 \\
0 \\
0 \\
0 \\
0 \\
0\end{array}$ & $\begin{array}{l}0 \\
0 \\
0 \\
0 \\
0 \\
0 \\
0 \\
0 \\
0 \\
0 \\
0 \\
0\end{array}$ & $\begin{array}{l}0 \\
0 \\
0 \\
0 \\
0 \\
0 \\
0 \\
0 \\
0 \\
0 \\
0 \\
0 \\
0 \\
0 \\
0 \\
0 \\
0 \\
0 \\
0 \\
0 \\
0 \\
0\end{array}$ & $\begin{array}{l}0 \\
0 \\
0 \\
0 \\
0 \\
0\end{array}$ & $\begin{array}{l}0 \\
0 \\
0 \\
0 \\
0 \\
0 \\
0\end{array}$ & $\begin{array}{l}0 \\
0 \\
0 \\
0 \\
0 \\
0 \\
0 \\
0 \\
0\end{array}$ & $\begin{array}{l}0 \\
0 \\
0 \\
0\end{array}$ & $\begin{array}{l}\Delta \\
\Delta \\
\Delta \\
\Delta \\
\Delta \\
\Delta \\
\Delta \\
\Delta \\
\Delta \\
\Delta \\
\Delta \\
\Delta\end{array}$ & $\begin{array}{c}13 \\
1 \\
1 \\
1 \\
1 \\
3 \\
2 \\
- \\
2 \\
- \\
1 \\
1 \\
4 \\
1 \\
- \\
1 \\
- \\
- \\
- \\
- \\
1 \\
1 \\
1 \\
1\end{array}$ & $\begin{array}{l}4 \\
5 \\
2 \\
1 \\
- \\
- \\
1 \\
1 \\
2 \\
6 \\
- \\
- \\
5 \\
7 \\
3 \\
5 \\
5 \\
2 \\
3 \\
2 \\
6 \\
9 \\
2 \\
2\end{array}$ \\
\hline & & & & & & & & & 計 36 & 73 \\
\hline
\end{tabular}

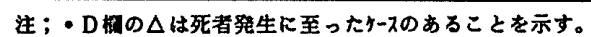

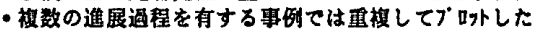

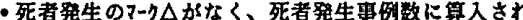
ている场合、死者発生のバターンむ同時に生じた事列が あることを示す。

図一5 火災事例（81 例）における火災フェイズの進展過程
A；フェイズ連続型
$\mathrm{B} ;$ 避難フェイズスキップ型
C; 初期フェイズスキップ型
D ; 2 段階スキップ型
$\mathrm{E} ;$ 火煙急襲型

A は典型的な火災拡大過程を示すもので，ほぼ火煙の 空間的拡大に対応して避難行動などが生じるフェイズの 進展を示している。B は避難中に煙が拡大し, 通常の迬 難ルートでは間に合わなくなる場合と，避難開始が遅栮 た場合と，煙に急激に直面した場合である。Cでは火苂 覚知はしたものの初期の対応をせずに避難した場合と, 火災覚知が遅れている場合である。また，Dは火災覚知 の遅れから，初期の対処はするものの，避難段階で火煙 に襲われる場合である。さらに，Eは火災覚知す遅れ， 火煙に急激に直面する場合である。

この 5 つの火災フェイズ進展の類型とその細分類別に 事例数をみたものが表一10である。この表に示される ように, 死者の発生している火炎は, 覚知フェイズのス キップ (覚知遅れ) やその後の避難フェイズのスキップ が生じているものが約 $70 \%$ をしめ, 避難に成功してい る事例の約 $30 \%$ と大きく差が生じている。な拈，連続 型で死者が発生しているのは，進展過程が異なる夕イプ と同じ火災事例のなかで生じている別の進展過程である 場合亡, その過程のある段階で避難できない人がいたこ とを示すものである。すなわち，警報などの初期の対応 が成功せず，フェイズの緊急度に応じた全館での対応状 態となっていなかったケースであるといえる。

フェイズ間の進展をマトリックスにした表一-11から みると, 通常の避難フェイズから緊急避難や脱出にいた るケースが，避難フェイズのまま避難終了する場合より も多く，64 ケース中 37 ケース，また緊急避難フェイズ でも脱出に移っているのが 46 ケース中 33 ケースみられ る。

分析対象が特異火災であるため，必ずしもこの表が般的なビル火災の傾向を表すものではないが，1つある

表一10 火災フェイズ進展の類型と事例数

\begin{tabular}{|c|c|c|}
\hline 頛型 事列数 & 死者なし & 死者発生 \\
\hline (1)連挬型 & $15(41.6 \%)$ & $11(15.1 \%)$ \\
\hline 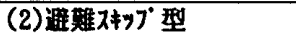 & $10(27.8 \%)$ & $11(15.1 \%)$ \\
\hline 谢奞幄れ & 5 & 1 \\
\hline 谁雉開始幄れ & 4 & 4 \\
\hline 急擏挞大 & 1 & 6 \\
\hline （3）切期 $x \neq 77^{\circ}$ 型 & $7(19.4 \%)$ & $20(27: 4 x)$ \\
\hline 初期対広迫れ & 1 & 5 \\
\hline 筧知幄坃 & 6 & 15 \\
\hline （4）2段階 $x^{\prime} \neq y 7^{\circ}$ 型 & $2(5.6 \%)$ & $27(37.0 \%)$ \\
\hline 觉知\&避難痋れ & - & 5 \\
\hline 筧知％避難閒始遇れ & - & 7 \\
\hline 党知\&対店失敗 & 2 & 15 \\
\hline (5)火煙急些型 & $2(5.6 \%)$ & $4(5.4 \%)$ \\
\hline
\end{tabular}


表一11 火災事例におけるフェイズ間推移

\begin{tabular}{|c|c|c|c|c|c|c|c|}
\hline to from & 0 & I & II & III & IV & $\mathrm{V}$ & VI \\
\hline $\begin{array}{l}0 \\
\text { I } \\
\text { II } \\
\text { III } \\
\text { IV } \\
\text { V } \\
\text { VI }\end{array}$ & $\begin{array}{r}- \\
48 \\
55 \\
- \\
3 \\
3 \\
-\end{array}$ & $\begin{array}{r}- \\
47 \\
1 \\
- \\
- \\
-\end{array}$ & $\begin{array}{r}- \\
63 \\
15 \\
24 \\
-\end{array}$ & $\begin{array}{r}- \\
28 \\
9 \\
-\end{array}$ & $\begin{array}{r}- \\
31 \\
2\end{array}$ & 40 & - \\
\hline $\begin{array}{l}\text { Success } \\
\text { Death }\end{array}$ & - & - & - & $\begin{array}{l}18 \\
(9)\end{array}$ & $\begin{array}{c}3 \\
(10)\end{array}$ & $\begin{array}{c}3 \\
(24)\end{array}$ & $\begin{array}{c}12 \\
(30)\end{array}$ \\
\hline
\end{tabular}

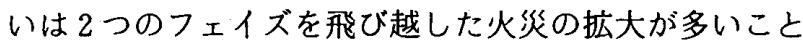
と，通常の避難行動のままでは終了しない場合が多いと いう傾向を示していることがわかる。つまり，避難安全 性評洒にあたって，避難流動特性を評価する以前の状況 設定が大きなウェイトをもつことを示している。

\section{3 火災フエイズの避難安全性評価に対する機能}

以上のように，火災フェイズの進展した段階とその過 程によって，火災の特徵と重大さが記述される。特に，

フェイズをスキップする過程を評価する必要があること がわかる。

このように，火災を非連続的な拡大過程として設定し た火災フェイズの考え方は，避難安全性の面からのビル 火災の拡大過程の把握を容易にしているといえる。これ は，設定した火災フェイズが人の行動を基準にして，単 一の指標ではなく，各種の起因によって形成されるとし ているためである。この点は複雑ではあるが，火災フェ イズを適用することによって，煙の噴出や情報の遅れや 避難遅れなどのフェイズ進展の起因が発生するか否かと いう, 避難安全性評価の状況と対策の位置ゔけが明らか にされる。

また，分析した火災事例にみられるように，一般に同 一火災の中でも空間による異なったフェイズ進展過程が ある。この火災フェイズと空間との関係については, 建 築の火災に対処すべき緊急状態という観点からみれば, 最も進展したある空間のフェイズを全館で対処すべき火 災フェイズとみなすことが防災計画上は適切であると考 えられる。

避難安全性の評価にあたっては, 建築の避難流動性を 評価する以前の，防災計画で守ろうとする状態にいたる 過程にウェイトがかかる。避難安全性の計画におけるこ の課題にたいして, 設定した火災フェイズの考え方は, 行動の緊急度を示すフェイズを安全性の尺度に,フェイ ズの進展の要因（起因発生の要因）に対して対策機能を 位置づけ，どの段階のフェイズまで進展するかによって 避難安全性を評価することである。また，火災性状の予 測評価手法を適用するにあたっては，評価する状況（目
標レベルのフェイズ) までの進展の過程とそのフェイズ の対策機能の状態を設定することが防災計画のストー リーにもとづく評価のシナリオとなるであろう。

\section{5. ‘結”論}

建築の火災拡大過程の時系列のモデルとして, 生活環 境の状態が非連続的に変化するという火災フェイズの考 え方にもとづいて，行動の起因にたいする行動種類の分 布の類似性から, 表一7に示す 7 段階からなる火災フェ イズを設定した。その結果, 分析対象とした火災事例く千 日〉とく大洋〉のうち，〈大洋〉については従業員と工 事関係者の行動が多様であったため, 必ずしもフェイズ ごとの行動の一様性は明確ではないものの, 人の”行動に ついても火災拡大過程のなかで様相の異なる局面がある ことが確認された。

そして, 火災㹡大過程を火災フェイズの進展として類 型的によらえ，フェイズの段階とそれまでの進展過程に より, 避難安全性からみたビル火災の特徴が記述できた。 したがって，設定した火災フェイズは避難安全性からみ た火災拡大過程のモデルとすることができるものと考え られる。

この火災フェイズの特徵は, 従来の火災拡大過程のモ デルにたいし，人の行動を基準にした建築の緊急度の観 点からフェイズを定義していることである。そのため, フェイズ進展は単一指標ではなく，各種の起因によって 生じている。したがって, 設定した火災フェイズを全館 の避難安全性の評価に適用するには，起因をベースにし てフェイズ進展の要因分析を行うことが課題となる。

\section{6.おわりに}

行動記述から設定した火災フェイズは，ごく一般的に 解釈される行動状態の変化と類似するものであるが, 行 動からみても様相の異なる局面があることと, その起因 が確認され，ビル火災に適用できることに意義があると 考えられる。

次報は，より火災フェイズを物理的現象と対応させる ために，実火災からフェイズが進展する条件の要因分析 により,対策機能の位置づけを明らかにする予定である。

末筆ながら，建築計画における安全性の考え方や防災 計画の考え方などにご指導いただいた伊藤 誠千葉大学 教授, 守屋秀夫千葉大学教授, 太田利彦清水建設（株） 技術研究所所長，ならびに建築学会建築計画委員会安全 計画小委員会の皆様に謝意を表します。

注

1) ここでは, 防災計画のストーリーとは非常時の事態にた いする対策の組み立てとし，評価のシナリオとは安全性 を評価する事態の発生過程の筋書を意味するものとして いる。本報では，評価にあたっての条件設定を防災計画 
のストーリーにもとづいたシナリオによって設定すると いう，設計的視点にたった計画方法を目指しているもの である。

2) 主に，火災実態の調查，避難シミュレーション，防災対 策のシステム論的アプローチ, 安全性評価が研究の対象 となった。これらの先駆的な研究のみを挙げると, 建築 計画からみた火災実態調查には村上處直, 高野公男ほか による「災害空間の考察，その1〜3」(昭和 47 年度日本 建築学会大会梗概）が挙げられる。避難シミュレーショ ンについては渡辺仁史，吉田克之ほかによる「人間一空 間系の研究，その1〜4」(昭和 48 年度日本建築学会大会 梗概）が先駆となった。防災対策のシステム論的アプロー チについては, 寺井俊夫による信頼性を考慮した防災シ ステム構成の考え方として,「火災に対する建物の安全計 画法に関する研究，その 1，2」(昭和 47 年度日本建築学 会大会梗概）がある。安全性評価には建設省建築研究所 による住宅性能総合安全システムの開発が挙げられる(昭 和 51 年度建築研究所年報, 1977)。

3）筆者による昭和 56 年日本建築学会学術講演梗概集 No. 5054 「行動からみた火災の状態の段階づけ」は，この章 の趣旨を記したものである。しかし，起因の分類を大き くまとめていたことと，フェイズ設定にあたっての類似 度によるまとめかたが定性的であったため，再度同趣旨 で検討を加えたものである。その結果，火災フェイズの

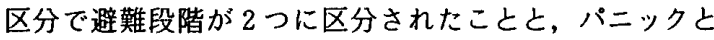
救助を同じ段階に位置づけた点で相違が生じた。

4） デパートとゲームコーナーとキャバレーからなる7階建 のビルである。 3 階の工事中の階から昭和 47 年 5 月 13 日 $22: 27 こ ろ$ 出火し, 空調レタンダクトやエレベータ シャフトをとおして 7 跸の営業中のキャバレーに煙が伝 播した。7階には警報もなかったことから，在館者は逃 げ場を失い，狭い所に閉じ込もる者，窓から飛び降りる 者などパニックになり，118 人の死者をだした火災であ る。

5）9階建の基準階約 $2100 \mathrm{~m}^{2}$ の百貨店における営業中の火 災で，当時は増築工事中であった。昭和 48 年 11 月 29 日 $13: 15$ ころ, 階段室の 2 階と 3 階の間に膡かれていた物 品の所から出火し，階段ならびに工事中の中央エスカレー 夕部分を伝わって火煙が全館に伝播した。客は少なかっ たが，非常放送がなされなかったこともあり，避難開始 が遅れ，また窓も遮閉されており，避難者は逃げ場を失い， 103 人が死亡した $(3 \mathrm{~F} ; 1$ 人， $4 \mathrm{~F} ; 40$ 人， $5 \mathrm{~F} ; 1$ 人，6F; 31 人, $7 \mathrm{~F} ; 29$ 人, $8 \mathrm{~F} ; 1$ 人)。

火災概要は次の文献に報告されている。態本市消防局 予防課, 「態本市大洋デパートの火災概要」, 火災 Vol.24, No. 3, 日本火災学会, 1974

6）当時, この火災の調查団の協力員として調查に参加し, 熊本市消防局からデータを収録させていただいたもので ある。詳細な属性はカットされているデータである。

7) 行動科学における刺激と反応のモデルは, 社会的役割や 個人の属性が影響する社会的行動には適当ではなく，ク ルト・レビンの行動モデル $B=f(e, h)$ (行動は環境と 個人の属性を要素として決定される) の考え方が妥当と 考えられている。本論の分析は，マクロにみて，行動に 影響する現象を把握することを目的にしていることと， 調查対象が主に従業員で社会的属性の差は小さいことに
より，環境と行動の関係のみで分析している。

8）行動と火災状態との関係は建築物内の場所の違いにより, 同じ記述でも時間的相違がある。しかしここでは行動 に変化を与える状態を把握する考え方に限っているため, 起因之行動の関係のみに分析を絞ったものである。

9）生態学において地域の生態的類似性を種の分布により指 標化する手法である。この多㥞度はサンプルが同じ種に 該当する確率を示している。この手法の特徵はデー夕数 やデータの統計的分布に左右されない指標であることで ある。 $\lambda_{l}$ は 0 に近いほど多様であることを示し， $C_{t}$ は 1 に近いほよ゙ $i$ と $j$ 間で類似していることを示す。ただ し，データの分布によって $C_{l j}$ は 1 より大きくなる。

\section{参考文献}

1）建設省大臣官房技術調查室監修：建築物の総合防火設㨽 法，（財）日本建築センター，平成元年 4 月

2）北沢五郎：百貨店における防火避難対策についての私案: 昭和 8 年度日本建築学会大会論文, 建築雑誌昭和 8 年 4 月号, pp. 523 -536, 日本建築学会, 昭和 8 年 4 月

3）戸川喜久二：群集流の観測に基づく避難施設の研究，建 築研究報告 No. 14, pp. 1 40, 建設省建築研究所, 昭和 30 年 2 月

4）上田光雄：階段における群集流動の性状，日本建築学会 諭文報告集 No. 55, pp. 94 99, 日本建築学会, 昭和 32 年 2 月

5）太田利彦：昭和 47 年度日本建築学会大会連合矿究協議会 記録「建築の安全性とは何か」, 建築雑誌 Vol. 88, No. 1062 , pp. 189 - 191, 日本建築学会, 昭和 43 年 3 月

6）建設省住宅局建築指導課監修：新建築防災計画指針，日 本建築センター, 昭和 60 年 6 月

7）志田弘二, 过本 誠ほか：火災発生に伴う人命危険の評 価法, 日本建築学会論文報告集, No. 368, pp. 69 78, 日本建築学会, 昭和 61 年 10 月

8）室崎益輝，中山 聡ほか：火炎覚知過程および避難開始 時間に関する研究 (その 1 , その 2 ), 昭和 61 年度日本建 築学会学術講演梗概集 No. 5362, No. 5363, pp. 723 726, 日本建築学会, 昭和 61 年 8 月

9）矢代嘉郎：避難安全性評価における設定条件の影響度， 昭和 63 年度日本建築学会学術講演梗概集 No. 5290, pp. 579 580, 日本建築学会, 昭和 63 年 10 月

10）鈴木成文, 守屋秀夫, 太田利彦：建築計画, 奏:教出版, 昭和 50 年 10 月

11）佐藤武夫ほか：災害論, 勁草書房, 昭和 39 年

12）高野公男ほか：済生会八幡病院火災の考察, 建筑防火 No. 78 特集「建築計画からみた火災の調查研究」, pp. 24 ３7, (社) 日本科学防火協会, 昭和 48 年 5 月

13）守屋秀夫：建築の防災設計 2-2 総合的防災対策, 日本开 ムシング (株), 昭和 53 年 1 月

14) Nelson, Harold E. : Systems Approach to Fire Protection Requirement for Building，昭和 51 年度 UJNR 講演 梗概集, General Service Administration (USA), 1976

15）森下弥三郎：住宅における火災拉大過程に関する統計的 考察, 昭和 52 年度日本火災学会研究発表会梗概集, 日本 火災学会, 昭和 52 年 5 月

16）青木義次：火災フェイズの拡大に関する確率馀的研究, 昭和 52 年度日本建築学会学術講演梗概集 No. 5084, 
pp. 713 714, 日本建築学会, 昭和 52 年 10 月

17）消防庁予防救急課編集：建築物防災システム実態調查, 建築物の総合防災システムの評価指針第 1 巻第 2 章, (株) ぎょうせい, 昭和 61 年 11 月

18) Malasky, Sol W. : System Safety, Hayden Book Company, inc., 1974

19）高圧ガス保安協会編集：コンビナート保安防災技術指針, 高圧ガス保安協会, 昭和 49 年

20）橋本邦衛: : 安全人間工学, 中央労働防止協会, 昭和 59 年

21）渡辺仁史：オートマタ理論による建物からの避難行動の 解析, 昭和 48 年度日本建築学会学術講演梗概集, pp. $641 \sim 642$, 日本建築学会, 昭和 48 年 10 月

22）三村由夫：防災計画の組み立て，建設省住宅局建築指導 課監修, 新建築防災計画指針第 1 章 1-2, 日本建築セン
夕一, 昭和 60 年 6 月

23）大阪市消防局：千日デパート火災関係者質問調書事項抜 粋, 建築防火臨時增刊, 千日デバート火災総集号, pp. 132 140, (社) 日本科学防火協会, 昭和 47 年

24）小林正美, 堀内三郎：オフィスビルにおける火災時の人 間行動の分析（1）（2）, 日本建築学会論文報告集 No. 280, pp. 137 142, No. 284, pp. 119 124, 日本建築学会, 昭 和 54 年 6 月, 昭和 54 年 10 月

25）田川日出夫：生態遷移研究法，共立出版，昭和 54 年 3 月

26）東京消防行政研究会編：火災の実態から見た危険性の分 析之評価一特異火災 112 例一, 全国加除法令出版 (株), 昭和 58 年 4 月

(1990 年 1 月 10 日原稿受理, 1990 年 6 月 5 日採用決定) 